\title{
Giant hiatal hernia: beware of the supine ICU chest X-ray!
}

\author{
Vincent Bunel, ${ }^{1,2}$ Pierre Mordant, ${ }^{2,3}$ Lara Ribeiro, ${ }^{4}$ Bruno Crestani ${ }^{1,2}$
}

\begin{abstract}
- Additional material is published online only. To view please visit the journal online (http://dx.doi.org/10.1136/ bcr-2017-219668)
\end{abstract}

'Bichat Hospital, Department of Pneumology A, DHU Fire, Assistance Publique - Hopitaux de Paris, Paris, France

${ }^{2}$ Universite Paris Diderot UFR de Medecine Site Xavier-Bichat, Paris, France

${ }^{3}$ Bichat Hospital, Department of Vascular and Thoracic Surgery, Assistance Publique - Hopitaux de Paris, Paris, France

${ }^{4}$ Bichat Hospital, Department of General and Digestive Surgery, Assistance Publique - Hopitaux de Paris, Paris, France

\section{Correspondence to}

Dr Vincent Bunel,

vincent.bunel@gmail.com

Accepted 15 March 2017

\section{(a) CrossMark}

To cite: Bunel V, Mordant $P$, Ribeiro L, et al. BMJ Case Rep Published Online First: [please include Day Month Year]. doi:10.1136/bcr-2017 219668

\section{DESCRIPTION}

An 85-year old woman with a medical history of mild hiatal hernia was admitted to the medical intensive care unit for respiratory distress associated with hypoxaemia and hypercapnia. A diagnosis of cardiogenic oedema was suspected. The situation slightly improved after high-dose diuretics and non-invasive ventilation. The anteroposterior supine chest X-ray revealed a right thoracic opacity. The patient was transferred to the pulmonology unit. A classical erected posteroanterior chest X-ray revealed a large air-fluid level in the right hemithorax (figure 1). An hydropneumothorax or a lung abscess was suspected. A chest CT scan revealed a giant hiatal hernia containing the stomach, the first duodenum, the spleen, the caudal part of the pancreas and the left colic flexure, all elevated in the right hemithorax (figure $2 \mathrm{~A}-\mathrm{C}$; video 1). A laparoscopic surgical procedure was performed which involved the excision of the hernia sac, a suture repair of crural pillars, with oesophagogastropexy and an antireflux valve creation (figure 2D-F).

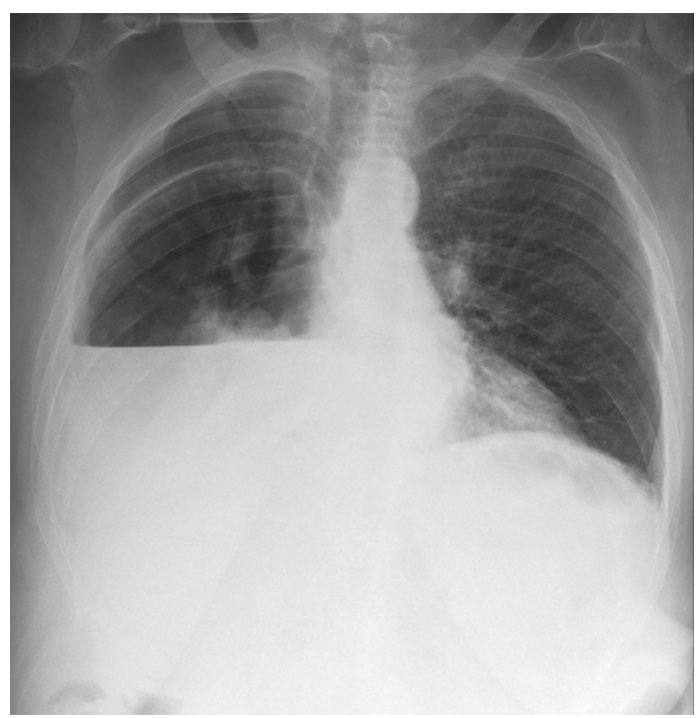

Figure 1 Posteroanterior chest X-ray showing large right chest opacity with air-fluid level on the right part of the thorax. The right hemidiaphragm is not visible.

\section{Learning points}

- Beware of anteroposterior supine chest X-ray.

- Think of hiatal hernia for all hydro-aeric opacity in the thorax, even on the right side.

- Giant hiatal hernia surgery can improve dyspnoea.
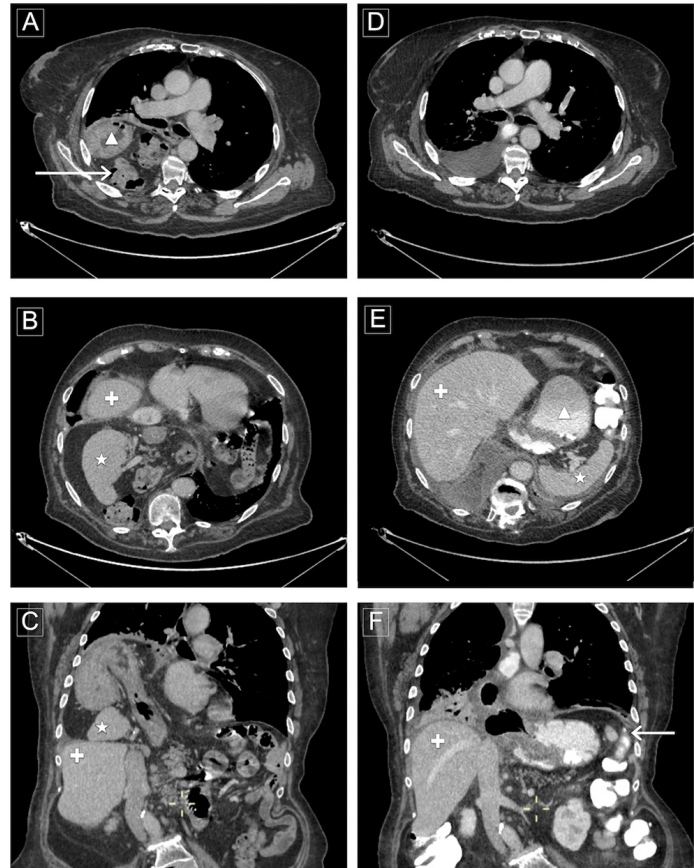

Figure 2 CT scan before $(A, B, C)$ and after $(D, E, F)$ surgery. The stomach $(A, E$, triangle), left colonic flexure $(A, F$, arrow) and spleen $(C, E$, star) are visible in the hernia sac and in their right position after surgery; the liver is marked by a cross $(B, C, D, E)$. Postoperative $C T$ images show moderate postoperative pleural effusion (D) and significant diminution of hiatal hernia (F).

The postoperative period was uneventful and the patient was discharged on postoperative day 13 . Comparison of the preoperative and postoperative work-up showed a great improvement in dyspnea (Modified Medical Research Council (mMRC) Dyspnea Scale 2 vs mMRC 4 before surgery), room air oxygen saturation $\left(\mathrm{SpO}_{2}=97 \%\right.$ vs $\left.90 \%\right)$ and lung function (forced vital capacity $=107 \%$ predicted vs $48 \%$ predicted). Huge hiatal hernia is particularly observed in elderly, and may cause dyspnoe ${ }^{1}$ and cardiac failure due to heart compression. ${ }^{2}$ Surgical repair is usually associated with a significant improvement of both symptoms and in pulmonary function tests.

Contributors Conception and design: $\mathrm{VB}, \mathrm{BC}$. Analysis and interpretation: $V B, P M, L R, B C$. D rafting the manuscript for important intellectual content: $\mathrm{VB}, \mathrm{PM}, \mathrm{BC}$.

Competing interests None declared.

Patient consent Obtained.

Provenance and peer review Not commissioned; externally peer reviewed 


\section{Images in...}

(c) BMJ Publishing Group Ltd (unless otherwise stated in the text of the article) 2017. All rights reserved. No commercial use is permitted unless otherwise expressly granted.

\section{REFERENCES}

1 Sahin C, Akın F, Cullu N, et al. A large Intra-Abdominal hiatal hernia as a rare cause of dyspnea. Case Rep Cardiol 2015;2015:1-4.

Copyright 2017 BMJ Publishing Group. All rights reserved. For permission to reuse any of this content visit http://group.bmj.com/group/rights-licensing/permissions.

BMJ Case Report Fellows may re-use this article for personal use and teaching without any further permission.

Become a Fellow of BMJ Case Reports today and you can:

- Submit as many cases as you like

Enjoy fast sympathetic peer review and rapid publication of accepted articles

Access all the published articles

Re-use any of the published material for personal use and teaching without further permission

For information on Institutional Fellowships contact consortiasales@bmjgroup.com

Visit casereports.bmj.com for more articles like this and to become a Fellow
2 Matar A, Mroue J, Camporesi E, et al. Large hiatal hernia compressing the heart. Am Cardiol 2016;117:483-4.

3 Carrott PW, Hong J, Kuppusamy M, et al. Repair of giant paraesophageal hernias routinely produces improvement in respiratory function. J Thorac Cardiovasc Surg 2012;143:398-404. 